\title{
Identification of Thyroid Hormone Receptor Active Compounds Using a Quantitative High-Throughput Screening Platform
}

\author{
Jaime Freitas ${ }^{1,5}$, Nicole Miller ${ }^{2}$, Brenda J. Mengeling ${ }^{3}$, Menghang Xia ${ }^{2}$, Ruili Huang ${ }^{2}$, Keith Houck ${ }^{4}$, \\ Ivonne M.C.M. Rietjens ${ }^{1}$, J. David Furlow ${ }^{3, *, \#}$ and Albertinka J. Murk ${ }^{1,6, \#}$
}

\author{
${ }^{I}$ Division of Toxicology, Wageningen University, Tuinlaan 5, 6703 HE Wageningen, The Netherlands \\ ${ }^{2}$ National Center for Advancing Translational Sciences, National Institutes of Health, Bethesda, MD, 20892, USA \\ ${ }^{3}$ Department of Neurobiology, Physiology, and Behavior, University of California, Davis 95616, USA \\ ${ }^{4}$ National Center for Computational Toxicology, Office of Research and Development, U.S. Environmental Protection \\ Agency, Research Triangle Park, North Carolina 27711, USA \\ ${ }^{5}$ Group of Cell Activation and Gene Expression, Institute for Molecular and Cellular Biology, University of Porto, \\ Porto, Portugal \\ ${ }^{6}$ Subdepartment of Environmental Technology, Wageningen University, and Wageningen-IMARES, Axis Z (Building \\ number 118), Room TT.1.100, Bornse Weilanden 96708, WG Wageningen, The Netherlands
}

\begin{abstract}
To adapt the use of GH3.TRE-Luc reporter gene cell line for a quantitative high-throughput screening (qHTS) platform, we miniaturized the reporter gene assay to a 1536-well plate format. 1280 chemicals from the Library of Pharmacologically Active Compounds (LOPAC) and the National Toxicology Program (NTP) 1408 compound collection were analyzed to identify potential thyroid hormone receptor (TR) agonists and antagonists. Of the 2688 compounds tested, eight scored as potential TR agonists when the positive hit cut-off was defined at $\geq 10 \%$ efficacy, relative to maximal triiodothyronine $\left(T_{3}\right)$ induction, and with only one of those compounds reaching $\geq 20 \%$ efficacy. One common class of compounds positive in the agonist assays were retinoids such as all-trans retinoic acid, which are likely acting via the retinoid-X receptor, the heterodimer partner with the TR. Five potential TR antagonists were identified, including the antiallergy drug tranilast and the anxiolytic drug SB 205384 but also some cytotoxic compounds like 5-fluorouracil. None of the inactive compounds were structurally related to $\mathrm{T}_{3}$, nor had been reported elsewhere to be thyroid hormone disruptors, so false negatives were not detected. None of the low potency $(>100 \mu \mathrm{M}) \mathrm{TR}$ agonists resembled $\mathrm{T}_{3}$ or $\mathrm{T}_{4}$, thus these may not bind directly in the ligand-binding pocket of the receptor. For TR agonists, in the qHTS, a hit cut-off of $\geq 20 \%$ efficacy at $100 \mu \mathrm{M}$ may avoid identification of positives with low or no physiological relevance. The miniaturized GH3.TRELuc assay offers a promising addition to the in vitro test battery for endocrine disruption, and given the low percentage of compounds testing positive, its high-throughput nature is an important advantage for future toxicological screening.
\end{abstract}

Keywords: Endocrine disruption, pituitary cells, quantitative high-throughput screening, thyroid hormone receptor, reporter gene assay, retinoid-X receptor.

\section{INTRODUCTION}

The vertebrate thyroid hormone (TH) system isan elaborate signaling network that controls critical processes through different life-stages,such as regulation of fuel metabolism [1], proliferation versusdifferentiation, development and maintenance of brain function [2-4], thermoregulation [5], osmoregulation and renal function [6], seasonal reproductive behaviour and fertility $[7,8]$, cardiovascular function $[9,10]$, and special senses [11]. Potential alterations to the TH system by natural or synthetic compounds present in our

*Address correspondence to this author at the Department of Neurobiology, Physiology, and Behavior, University of California, Davis, CA 95616; Tel: (530)754-8609; Fax: (530) 752-5582. E-mail: jdfurlow@ucdavis.edu ${ }^{\#}$ Both authors contributes equally. food or the environment could therefore have substantial implications. In this context, the demonstration that certain manufactured chemicals exhibit thyroid hormone-like activity $[12,13]$ generated an interest in the many potential adverse outcomes of TH system disruption. The TH signaling network relies on efficient and accurate interpretation of these extracellular chemical signals by the thyroid receptors (TRs) [1]. Thyroid active compounds may interact at the level of these TRs but may also generate effects at several other targets in a normal functioning TH endocrine system. These include TH transport by transthyretin (TTR) or thyroxine-binding globulin (TBG) [14]; hormone production which depends on iodine uptake [15] and the enzyme thyroid peroxidase (TPO) to incorporate iodine onto tyrosinesof thyroglobulin [16]; hormone activation or deactivation by iodothyronine deiodinases types I, II, and III (D1, D2, and D3, 
respectively), which regulate the activity of thyroid hormones via removal of specific iodine substituents [17, 18]; UDP glucuronosyltransferases (UGTs) or sulfotransferases (SULTs) which conjugate the thyroid hormones and facilitate their excretion from the body [19]; or transporters of thyroid hormones through the target cell membrane [20]. Although in vitro assays have already been developed for several of these targets [21], current risk assessment strategies still rely heavily on chemical safety data obtained in animal models. This low-throughput approach is relatively expensive and may provide an unreliable representation of human toxicity. Furthermore, the use of large numbers of animals for toxicity testing raises legal and ethical considerations. The development of integrated and intelligent testing strategies for toxicity evaluation, such as innovative in vitro and in silico approaches, has paved the way for the reduction of vertebrate studies. The regulatory system for chemicals controlled by the European Chemical Agency (ECHA), called Registration, Evaluation and Authorization of Chemicals (REACH) has placed a premium on functional, quantitative, high-throughput, in vitro screening assays (qHTS) for the toxicological evaluation of the extraordinarily high number of natural and synthetic chemicals to be assessed within a few years (about 30,000 substances are currently marketed at volumes greater than 1 ton/year). In addition, a collaboration known as Tox21, comprised of the United States Environmental Protection Agency (US EPA), the US National Institutes of Health (NIH), and the US Food and Drug Regulatory Agency (FDA), has initiated a program of screening a large chemical library composed of environmental chemicals and pharmaceuticals through different qHTS assays developed based on specific biological mechanisms relevant to toxicity [22-24]. These screening assays directly assess the effects of thousands of chemicals on particular cellular systems or molecular targets. However, for TR-mediated disruption, a functional qHTS assay based on endogenous full-length receptors is still lacking. Recently, we have developed and validated a stably-transfected reporter gene cellular model in the TH-responsive rat pituitary tumor $\mathrm{GH}_{3}$ cell line that endogenously expresses both TR isoforms [25]. Here, we present the development and application of the GH3.TREluc cell line using a qHTS system in order to rapidly identify chemicals that alter TR activity, and therefore havethe potential for endocrine disruption. We miniaturized and optimized the GH3.TRE-Luc assay into a 1536-wells plate format for assaying potential agonistic, antagonistic and cytotoxic activities of the compounds tested. We used the optimized qHTS system to test the 1280 compounds of the LOPAC library (Library of Pharmacologically Active Compounds) [26] and the 1408 chemicals from the National Toxicology Program collection (NTP) [27]. To insure that observed effects were not due to cytotoxicity, we measured intracellular ATP content as a cell viability readout. These chemical collections were used for validation of the high-throughput screen (qHTS) because of the diverse chemical families they contain, some of which are proven to be pharmacologically active, and with almost all the compounds previously tested in one or more standard toxicological assays. The outcomes of this preliminary screen were further examined to identify potential false positives and false negatives using the publically available PubChem Bioassay database.

\section{MATERIALS AND METHODS}

\section{Cell Line and Culture Conditions}

The GH3.TRE-Luc cell line, developed as described [25], stably expresses a modified firefly luciferase reporter gene under the regulation of a pair of thyroid hormone response elements (TREs). Cells were routinely sub-cultured once a week in fresh $75-\mathrm{cm}^{2}$ culture flasks (Corning, Acton, MA), in a humid atmosphere at $37^{\circ} \mathrm{C}$ and $95 \%$ air $/ 5 \% \mathrm{CO}_{2}$ in Dulbecco's Modified Eagle's medium/Ham's F12 (DMEM:F12, Invitrogen, Carlsbad, CA) supplemented with $10 \%$ Fetal Bovine Serum (FBS, Hyclone, Logan, UT).

\section{qHTS TRE Luciferase Reporter Gene Assay}

For the TRE luciferase reporter gene assay GH3.TRELuc cells were seeded at $80 \%$ confluence in $225 \mathrm{~cm}^{2}$ culture flasks (Corning, Acton, MA) in regular growth medium and cultured overnight. Growth medium was then replaced by assay medium [28] (DMEM:F12 supplemented with 10 $\mu \mathrm{g} / \mathrm{ml}$ insulin, $10 \mu \mathrm{M}$ ethanolamine, $10 \mathrm{ng} / \mathrm{ml}$ sodium selenite, $10 \mu \mathrm{g} / \mathrm{ml}$ human apotransferrin and $500 \mu \mathrm{g} / \mathrm{ml}$ bovine serum albumin) followed by a $20 \mathrm{~h}$ incubation. Subsequently, cells were detached, re-suspended in assay medium. For agonist mode screening, cells were dispensed at 1500 cells/ 5 $\mu 1 /$ well in 1536-well white wall/solid bottom plates (Greiner Bio-One North America, NC, USA) using a Flying Reagent Dispenser (FRD) (Aurora Discovery, CA, USA). After the cells were incubated at $37^{\circ} \mathrm{C}$ for $4-5 \mathrm{~h}, 23 \mathrm{nl}$ of compounds at 7 to 14 concentrations or DMSO control were transferred using a Pintoolstation (Wako, San Diego, CA) into each well resulting in a final DMSO concentration of 0.46 or $0.92 \%$. For antagonist mode screening, cells were dispensed at 1500 cells/ $4 \mu \mathrm{l} /$ wellin 1536 -well white wall/solid bottom plates (Greiner Bio-One North America) using of FRD (Aurora Discovery). After test compounds were added as indicated above, $1 \mu \mathrm{l}$ of $1 \mathrm{nM}$ final concentration $\mathrm{T}_{3}$ or assay media control was dispensed to each well. The assay plates were incubated with compound treatment for $24 \mathrm{~h}$. After this incubation, $5 \mu$ of One-Glo luciferase reagent (Promega, Madison, WI) was added and plates were incubated at room temperature for $30 \mathrm{~min}$ before reading on a Viewlux plate reader (PerkinElmer, Waltham, MA).

For the primary screening, the 1280 compounds from the Library of Pharmacologically Active Compounds (LOPAC, Sigma, St. Louis, Missouri, USA) and the 1408 chemicals from the National Toxicology Program collection (NTP1408) [27] were tested in series of 7 to 14 dilutions with final concentrations ranging from $0.6 \mathrm{nM}$ to $92 \mu \mathrm{M}$ and $3 \mathrm{nM}$ to $46 \mu \mathrm{M}$ for the NTP and LOPAC collections, respectively. The highest concentrations tested were judged to be at the very upper range of potential environmental exposures. The four left columns in each plate were reserved for controls. The control format for the agonist mode plate was column-1 $\mathrm{T}_{3}$ from $0.3 \mathrm{pM}$ to $4.6 \mu \mathrm{M}$, column-2 $100 \mathrm{nMT}_{3}$ and column 3 to 4 DMSO only. The control format for the antagonist mode plate was column-1 to 2 DMSO only, column-3 to 48 $1 \mathrm{nMT}_{3}$.

For rescreening and testing nuclear receptor specific ligands, GH3.TRE-Luc cells were seeded at 150,000 cells/well in 24-well tissue culture plates (Greiner Bio One, 
Table 1. Assay Optimization in 1536-well Format.

\begin{tabular}{|c|c|c|c|}
\hline Cells/well $(\mathbf{5} \boldsymbol{\mu l})$ & $\mathbf{S} / \mathbf{B}$ & $\mathbf{E C}_{\mathbf{5 0}}$ (nM) & Z' factor \\
\hline \hline 1,000 & 9.18 & $0.33 \pm 0.032$ & 0.76 \\
\hline 1,500 & 7.13 & $0.55 \pm 0.036$ & 0.88 \\
\hline 2,000 & 9.49 & $0.39 \pm 0.038$ & 0.76 \\
\hline
\end{tabular}

Cells were plated $4 \mathrm{~h}$ prior to assay and stimulated with $\mathrm{T}_{3}$. Signal-to-background ratio (S/B) was calculated comparing the response of $4.6 \mu \mathrm{M} \mathrm{T}_{3}$ to $\mathrm{DMSO}_{\mathrm{S}}$ controls. EC $\mathrm{C}_{50}$ values were calculated from full dose response curves $(n=3)$. $Z$ ' factor was calculated using $T_{3} E_{100}(n=3)$.

Monroe, NC) in DMEM:F12 with 15 mM HEPES (GibcoInvitrogen, Grand Island, NY) supplemented with $10 \%$ fetal bovine serum (Gibco-Invitrogen) and Pen/Strep (GibcoInvitrogen). Twenty-four hours later, growth medium was replaced by PCM medium for an additional $24 \mathrm{~h}$. Cells were then incubated for $24 \mathrm{~h}$ in the presence or absence of the indicated ligands in $0.2 \%$ DMSO. Cell numbers were estimated using a BCA protein assay (Thermo Scientific, Rockford, IL) and luciferase activity was measured from lysed cells in a Hidex Chameleon V microplate luminometer using the Luciferase Assay System (Promega, Madison, WI). Each dose within an experiment was treated in duplicate, and each experiment was performed at least three times.

\section{Cell Viability Assay}

In order to exclude the compounds that inhibit TRinduced luciferase reporter gene expression due to cytotoxicity, the LOPAC and NTP libraries were also tested for cell viability by measuring intracellular ATP content using a luciferase-coupled ATP quantitation assay (CellTiter-Glo viability assay, Promega, Madison, WI). The cells were dispensed at 1500 cells $/ 5 \mu 1 /$ well in 1536-well white/solid bottom assay plates (GreinerBio-One North America) and the assay was run identically to the antagonist screen method mentioned above, with addition of $5 \mu \mathrm{l} /$ well of CellTiter-Glo reagent in place of One-Glo. After 30 minutes incubation at room temperature, the luminescence intensity was measured using a ViewLux plate reader (PerkinElmer).

\section{Data Analysis}

The primary data analysis was performed as previously described. Briefly, raw plate reads for each titration point were first normalized relative to the $T_{3}$ control $\left(100 \mathrm{nM} \mathrm{T}_{3}\right.$, set at $100 \%$ for agonist mode; $1 \mathrm{nM} \mathrm{T}_{3}$, set at $0 \%$ for antagonist mode) and DMSO only wells (basal, set at $0 \%$ for agonist mode and $-100 \%$ for antagonist mode), and then corrected by applying a pattern correction algorithm using compound-free control plates (DMSO plates) [29].

Concentration-response titration points for each compound were fitted to the Hill equation yielding concentrations for half-maximal activity for agonists $\left(\mathrm{EC}_{50}\right)$ or halfmaximal inhibition for antagonists $\left(\mathrm{IC}_{50}\right)$ and maximal response (efficacy) values. The concentration response curves of the compounds were classified into four major classes (1-4) based on the completeness of curve, goodness of fit, and efficacy [29]. Antagonists were identified using the selection criterion that their $\mathrm{IC}_{50}$ values should be at least three times lower than the $\mathrm{IC}_{50}$ in the viability assay to exclude cases of cytotoxicity.

\section{RESULTS}

\section{Assay Optimization and Miniaturization in the 1536-Well Plate Format}

The GH3.TRE-luc assay was initially miniaturized in a 1536 -well plate with a $5 \mu \mathrm{l}$ final assay volume. To find the optimal cell density for the well, three different cell numbers were tested after treatment with various concentrations of the known agonist, $\mathrm{T}_{3}$, ranging from $0.3 \mathrm{pM}$ to $4.6 \mathrm{uM}$ for $24 \mathrm{~h}$. The $\mathrm{EC}_{50}$ values of $\mathrm{T}_{3}$ obtained were $0.33,0.55$, and $0.39 \mathrm{nM}$ at cell densities of 1000,1500 , and 2000 cells/well, respectively (Table 1). The signal-to-background ratio $(\mathrm{S} / \mathrm{B})$ for these three cell densities was 7 to 9.5 fold. Z' factor value from the density of 1500 cells/well was 0.88 , which was the highest compared to other cell densities (1000 or 2000 cells/well). Therefore, we chose 1500 cells/well for use in subsequent studies.

We optimized conditions to screen for thyroid receptor antagonist activity. Antagonist action can be identified based on the ability of the test compound to block the effect of a sub-maximal concentration of the agonist $\mathrm{T}_{3}$. In order to determine the concentration of $T_{3}$ to be used for qHTS determination of antagonist activity, two concentrations slightly above the $\mathrm{EC}_{50}$ of $\mathrm{T}_{3}$ (Table 2) were tested. At both $\mathrm{T}_{3}$ concentrations the assay showed a similar $\mathrm{S} / \mathrm{B}$ ratio (3.6 and 3.7 fold) but the $1 \mathrm{nM} \mathrm{T}$ group gave a minimal CV (coefficient of variation, $7 \%$ ) compared to the $0.5 \mathrm{nM} \mathrm{T}_{3}$ group $(\mathrm{CV}$, $11 \%) . \mathrm{Z}$ factors [30] were 0.44 and 0.65 for the $0.5 \mathrm{nM}$ and 1 $\mathrm{nM} \mathrm{T}_{3}$ exposure groups, indicating that $1 \mathrm{nM}$ was a better concentration for screening for antagonist activity. This concentration represents one that optimizes a large screening window without significant loss of sensitivity to detecting antagonists due to receptor binding competition with the $T_{3}$. All further inhibition (antagonism) assays were run using 1 $\mathrm{nM}$ of $\mathrm{T}_{3}$ as the agonist.

\section{Identification of Potential TR Agonists by qHTS}

The qHTS GH3.TRE-luc assay was used to screen the LOPAC and NTP libraries for TR agonists and antagonists to provide a proof of principle for its use as a newly developed biomolecular screening tool. Structures of representative compounds that showed positive responses in the qHTS assay are shown in Fig. (1). For agonist screening, the concentration titration of $T_{3}$, used as a positive control, was 
Table 2. $T_{3}$ Concentration Optimization for Antagonist Mode Screening in 1536-well Format.

\begin{tabular}{|c|c|c|c|}
\hline $\mathbf{T}_{\mathbf{3}}(\mathbf{n M})$ & $\mathbf{S} / \mathbf{B}$ & $\mathbf{C V}(\%)$ & $\mathbf{Z}$ ' factor \\
\hline \hline 0.5 & 3.6 & 11.1 & 0.44 \\
\hline 1 & 3.7 & 7.0 & 0.65 \\
\hline
\end{tabular}

Cells were plated $4 \mathrm{~h}$ prior to assay and stimulated with $\mathrm{T}_{3}$. Signal-to-background ratio ( $\left.\mathrm{S} / \mathrm{B}\right)$ was calculated comparing the response of the respective $\mathrm{T}_{3}$ concentrations to DMSO controls. Coefficient of variation (CV) and $Z^{\prime}$ factor were calculated using the indicated $\mathrm{T}_{3}$ concentrations $(\mathrm{n}=2)$.

A<smiles>NC(Cc1cc(I)c(Oc2ccc(O)c(I)c2)c(I)c1)C(=O)O</smiles>

C<smiles>CC1=C(/C=C/C(C)=C/C=C/C(C)=C/C(=O)O)C(C)(C)CCC1</smiles>

E<smiles>CC1=C(/C=C/C(C)=C/C=C/C(C)=C/C=O)C(C)(C)CCC1</smiles>

G<smiles>CC(C)(CO)Cc1cc(C(C)(C)C)c(O)c(C(C)(C)C)c1</smiles>

J<smiles>NNC(=O)c1ccc(O)cc1</smiles>

K<smiles>COc1ccc(CCC(=O)Nc2ccccc2C(=O)O)cc1OC</smiles><smiles>CC#CCOC(=O)c1c(C)nc2sc3c(c2c1N)CCC(O)C3</smiles>

N<smiles>NC(Cc1cc(I)c(Oc2cc(I)c(O)c(I)c2)c(I)c1)C(=O)O</smiles>

D<smiles>CC1=C(/C=C/C(C)=C/C=C/C(C)=C/C(=O)O)C(C)(C)CCC1</smiles>

F<smiles>CC1=C(/C=C/C(C)=C/C=C/C(C)=C/C=O)C(C)(C)CCC1</smiles>

I<smiles>CN1Cc2sccc2C(c2ccc(O)c(O)c2)C1</smiles>

L<smiles>O=c1[nH]c2cc(C(F)(F)F)ccc2n1-c1cc(C(F)(F)F)ccc1O</smiles>

0<smiles>O=c1[nH]cc(F)c(=O)[nH]1</smiles><smiles>CC(=O)NNc1ccccc1</smiles>

Fig. (1). Chemical structures. A) Triiodothyronine $\left(\mathrm{T}_{3}\right)$, B) Thyroxine $\left(\mathrm{T}_{4}\right)$, C) Retinoic acid, D) 13-cis-retinoic acid, E) Trans-retinal, F) 13cis-retinal, G) CGP-7930, H) CGP-13501, I) SKF-89145 hydrobromide, J) 4-Hydroxybenzhydrazide, K) Tranilast, L) NS-1619, M) SB 205384, N) 5-Fluorouracil and O) 1-Acetyl-2-phenylhydrazine. 


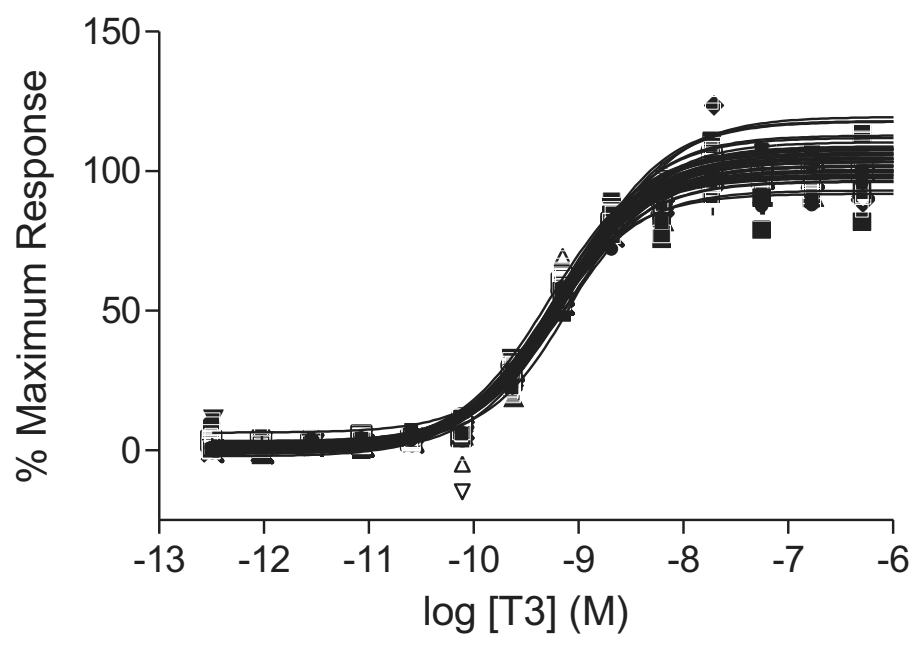

Fig. (2). The intra-plate $T_{3}$ dose-response curves for 27 different plates. In each plate $T_{3}$ was used as positive control. After plating at 1500 cells/well in 1536-well plates and incubated for $4 \mathrm{~h}$, cells were stimulated with the indicated concentration of $\mathrm{T}_{3}$ for $24 \mathrm{~h}$. Log $\mathrm{M} \mathrm{T}_{3}$ concentrations are indicated on the $\mathrm{x}$-axis.

Table 3. Screening Statistics for LOPAC and NTP Libraries.

\begin{tabular}{|c|c|c|c|c|c|c|}
\hline & \multicolumn{3}{|c|}{ Agonist Mode } & \multicolumn{3}{c|}{ Antagonist Mode } \\
\hline Library & CV $(\%)$ & S/B & Z' factor & CV (\%) & S/B & Z' factor \\
\hline \hline NTP & $9.21 \pm 1.81$ & $7.42 \pm 0.51$ & $0.77 \pm 0.05$ & $7.25 \pm 3.77$ & $4.71 \pm 0.29$ & $0.65 \pm 0.08$ \\
\hline LOPAC & $11.04 \pm 1.99$ & $6.88 \pm 0.54$ & $0.82 \pm 0.05$ & $7.83 \pm 1.27$ & $3.37 \pm 0.18$ & $0.76 \pm 0.04$ \\
\hline
\end{tabular}

Coefficient of variation (CV) calculated from control and low concentration plates. Signal-to-background ratio (S/B) and Z' factor for agonist and antagonist mode determined for $100 \mathrm{nM} \mathrm{T}_{3}$ and $1 \mathrm{nM} \mathrm{T}_{3}$, respectively.
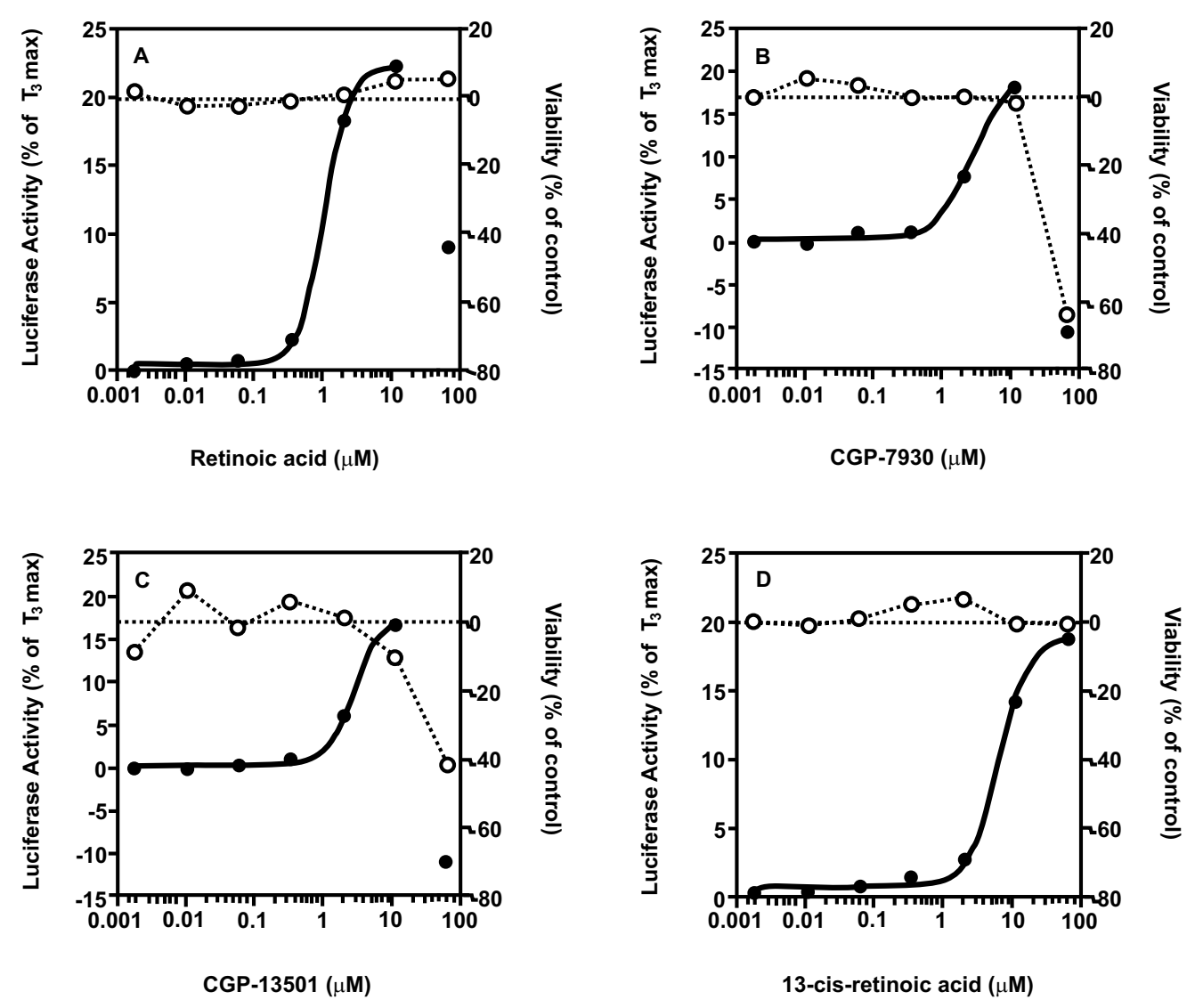

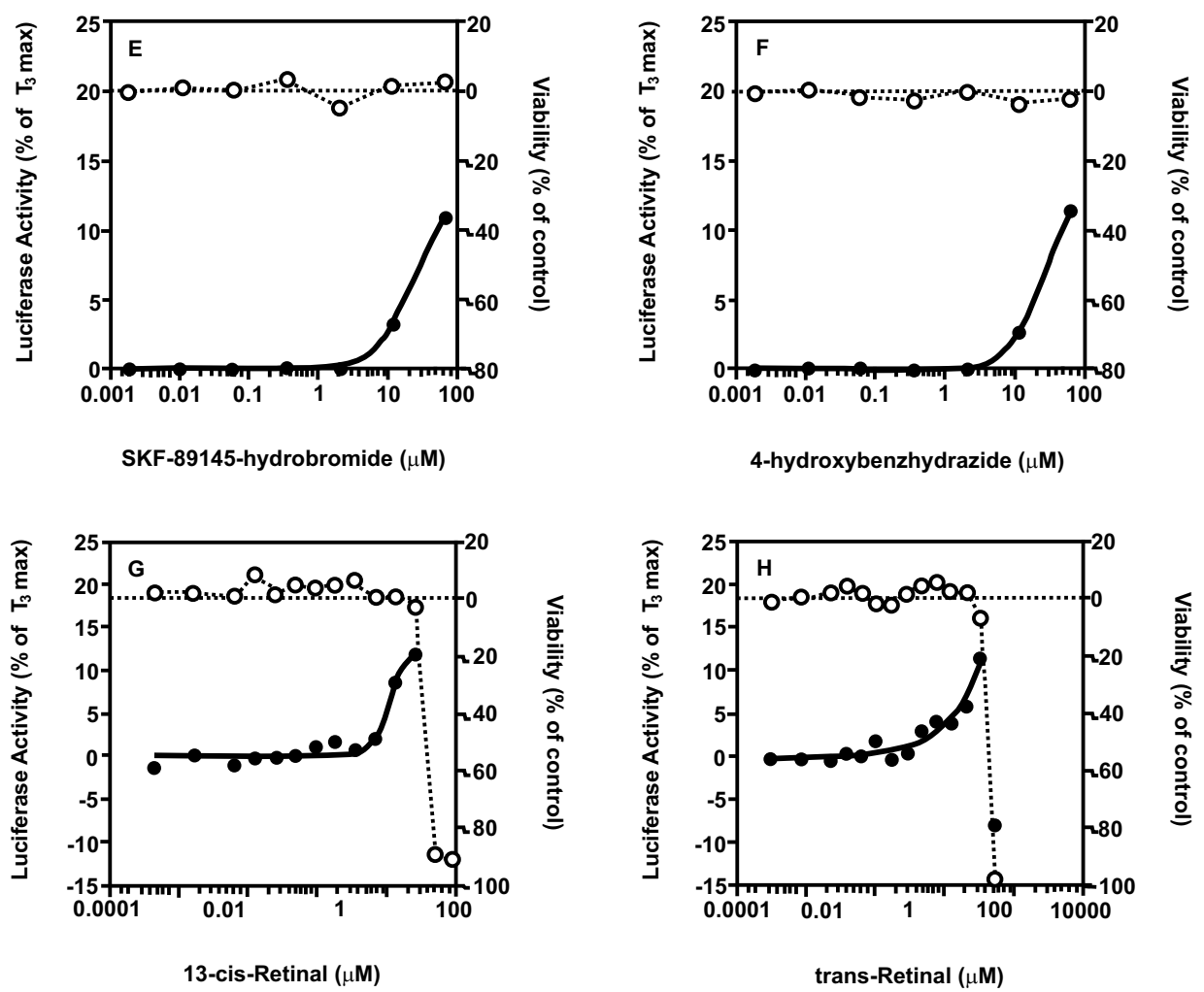

Fig. (3). Examples of agonists identified in the LOPAC and NTP libraries screening. Open circles, cell viability as a percentage (\%) of vehicle control values; closed circles, luciferase activity as a \% of vehicle control values, on the right and left y-axes respectively. Ligand concentrations in $\mathrm{mM}$ are indicated on the $\mathrm{x}$-axis.

performed in each plate. The control dose-response curves of $\mathrm{T}_{3}$ were well reproduced in all 27 plates used for the screening of the two libraries, including 6 DMSO plates, with an $\mathrm{EC}_{50}$ average of $0.66 \pm 0.13 \mathrm{nM}$ (Fig. 2). $\mathrm{T}_{3}$ controls averaged a signal-to-background ratio of 6.88 and 7.42 and the average $\mathrm{Z}$ factor was 0.82 and 0.77 in the LOPAC and NTP libraries screen, respectively (Table 3). Of the 1280 compounds from the LOPAC library, $6(0.5 \%)$ were identified as potential TR agonists (Fig. 3), with the positive hit cut-off being compounds that gave a $\geq 10 \%$ efficacy. The potency and efficacy of these compounds are listed in Table 4 . Of the 1408 compounds from the NTP library, $2(0.1 \%)$ were identified as potential TR agonists, with the positive hit cut-off being compounds that gave a $\geq 10 \%$ efficacy. The potency and affinity of these compounds are listed in Table 5. In order to evaluate the reproducibility of the hits in the qHTS format, the LOPAC library was re-screened three times. All 6 compounds identified from the primary screen showed similar activity in the re-screen (Table 4). When, for defining TR agonist activity, the positive hit cut-off was set at $\geq 20 \%$ efficacy, only one TR agonist, retinoic acid, was identified in the LOPAC library and none in the NTP library. Close evaluation of the dose response curves for the compounds that did not induce $\geq 20 \%$ efficacy, revealed that at the highest dose levels tested, 46 or $92 \mu \mathrm{M}$, maximum agonist activity may not yet have been reached for some of the compounds. However, given that the highest concentrations tested were generally considered to be at the upper end of possible exposure levels, we conclude that those compounds may not represent effective TR agonists. Furthermore, none of these compounds has structural characteristics that resemble the thyroid hormones $\mathrm{T}_{3}$ and $\mathrm{T}_{4}$ (Fig. 1), providing additional support for the conclusion that they may not represent effective direct TR agonists.

Retinoids detected as positives in the qHTS assay are likely acting as agonists via RXRs and not RARs, or RXRs complexed with permissive liver $-X$ receptors (LXRs)

In both the LOPAC and NTP1408 libraries, Vitamin A derivatives (retinoids) scored as positive hits in the agonist mode assay. This raised the possibility that in addition to the TRs, the system was responsive to retinoic acid receptors (RARs) or retinoid $\mathrm{X}$ receptors (RXRs), either alone or in known permissive heterodimer complexes with other nuclear receptors such as the liver $\mathrm{X}$ receptors (LXRs) [31]. However, neither the RAR-specific ligand TTNPB nor the LXRspecific ligand T0901317 activated the reporter gene, under conditions where both $\mathrm{T}_{3}$ and all-trans retinoic acid showed the expected induction profiles (Fig. 4).

\section{Identification of Potential TR Antagonists by qHTS}

To identify potential TR antagonists using this GH3.TRE-luc assay, the LOPAC and NTP libraries were screened in the antagonist mode, where cells were exposed 
Table 4. Potency and Efficacy for Compounds Identified in the LOPAC Library Screening.

\begin{tabular}{|c|c|c|}
\hline Agonists & Potency, $\boldsymbol{\mu M}($ Re-Screen) & Efficacy, \% (Re-Screen) \\
\hline \hline retinoic acid & 0.8 & $18.2(18.0)$ \\
\hline CGP-7930 & $2.7(2.6)$ & $16.8(15.0)$ \\
\hline CGP-13501 & $2.8(2.3)$ & $18.8(15.5)$ \\
\hline 13-cis-retinoic acid & $6.4(2.9)$ & $10.9(16.5)$ \\
\hline SKF-89145 hydrobromide & $21.9(20.6)$ & $11.5(17.5)$ \\
\hline 4-hydroxybenzhydrazide & $24.6(26.0)$ & $-86(-81.8)$ \\
\hline Tranilast & Antagonists & $-75(-73.0)$ \\
\hline SB 205384 & $0.7(0.8)$ & $-58(-75.7)$ \\
\hline NS-1619 & $2.6(2.5)$ & $-72(-71.1)$ \\
\hline 5-fluorouracil & $5.2(13.4)$ & $5.2(3.1)$ \\
\hline
\end{tabular}

Potency $\left(\mathrm{EC}_{50}\right.$ and $\left.\mathrm{IC}_{50}\right)$ values were calculated from full dose response curves in the absence and presence of $\mathrm{T}_{3}(1 \mathrm{nM})$, respectively. Efficacy was defined as percentage of maximal induction (agonist mode) or inhibition (antagonist mode) relative to $\mathrm{T}_{3}$ set at $100 \%$ (100 nM for testing of agonist and $1 \mathrm{nM}$ for antagonist activity). Average of re-screen values listed in parentheses.

Table 5. Potency and Efficacy for Compounds Identified in the NTP Library Screening.

\begin{tabular}{|c|c|c|}
\hline Agonists & Potency, $\boldsymbol{\mu M}$ & Efficacy, $\%$ \\
\hline \hline 13-cis-retinal & 7.1 & 11.8 \\
\hline trans-retinal & 14.9 & 11.4 \\
\hline \multicolumn{2}{|c|}{ Antagonists } \\
\hline 5-fluorouracil & 6.7 & -86.7 \\
\hline 1-acetyl-2-phenylhydrazine & 10.6 & -87.5 \\
\hline
\end{tabular}

Potency $\left(\mathrm{EC}_{50}\right.$ and $\mathrm{IC}_{50}$ ) values were calculated from full dose response curves in the absence and presence of $\mathrm{T}_{3}(1 \mathrm{nM})$, respectively. Efficacy was defined as percentage of maximal induction (agonist mode) or inhibition (antagonist mode) relative to $\mathrm{T}_{3}$ set at $100 \%$ (100 $\mathrm{nM}$ for testing of agonist and $1 \mathrm{nM}$ for antagonist activity).

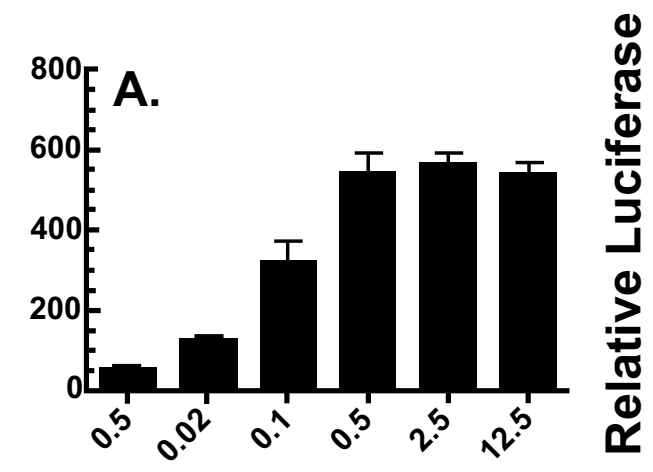

[T3] (nM)
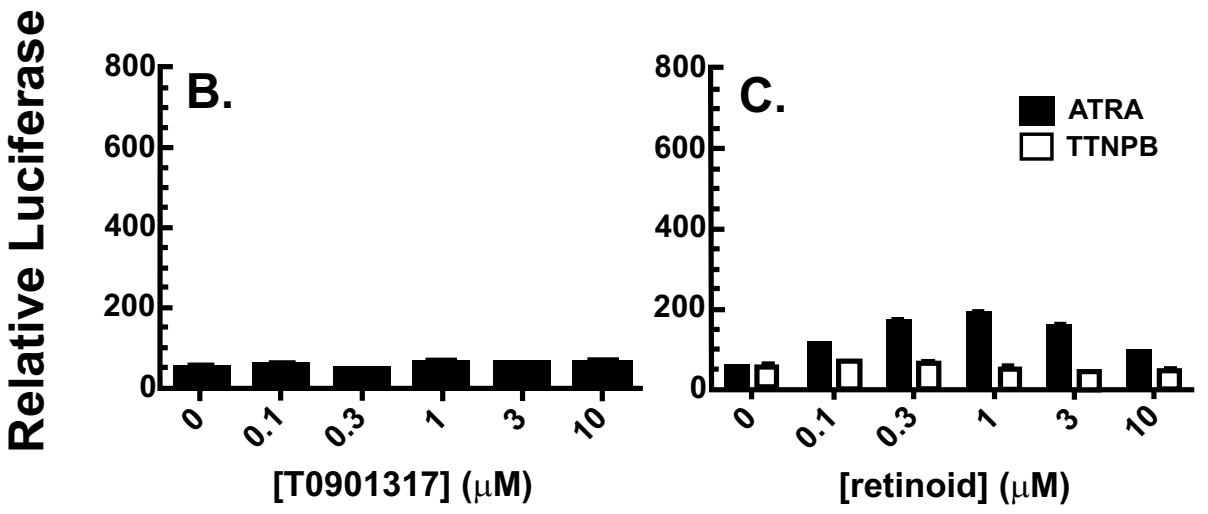

Fig. (4). GH3.TRE-LUC cells are activated by $T_{3}$ and all trans retinoic acid but not RAR or LXR specific ligands. A. Dose response curve of $\mathrm{T}_{3}$ induced reporter gene luciferase values in a 24 well format, normalized to total protein values. B. Lack of induction of the reporter gene luciferase activity by any concentration of an LXR specific ligand (T0901317). C. Low induction of the reporter gene luciferase activity by all trans retinoic acid (ATRA; black bars) consistent with the qHTS results, but not by the RAR specific ligand TTNPB (white bars). Concentrations of ligands in $\mathrm{nM}$ (for $\mathrm{T}_{3}$ ) and $\mu \mathrm{M}$ (all other compounds) are indicated on the $\mathrm{x}$-axis. 
to the test compounds in the presence of $1 \mathrm{nM} \mathrm{T}_{3}$, and the ability of the compounds to inhibit $\mathrm{T}_{3}$-mediated TR activation was measured. The average signal-to-background ratio was 3.37 and 4.71 , and the average $Z$ factor was 0.76 and 0.65 for the LOPAC and NTP libraries, respectively. To ascertain that the inhibitory effect of the potential hits was not due to cytotoxic effects, a cell viability screening was performed in parallel. Compounds that are known inhibitors of luciferase activity or expression, such as cycloheximide that is a potent translation inhibitor present in the LOPAC library, were removed from further consideration as an additional filter. From the LOPAC screen, 4 compounds $(0.3 \%)$ were identified with an $\mathrm{IC}_{50}$ that was 3 -fold lower than their viability $\mathrm{IC}_{50}$. The potency and efficacy of these compounds are listed in Table $\mathbf{4}$ and graphs are given in Fig. (5). From the NTP library, 2 compounds $(0.1 \%)$ were identified using the same selection criteria. The potency and efficacy of these compounds are listed in Table $\mathbf{5}$ and graphs are given in Fig. (5). In order to evaluate the reproducibility of the hits in the qHTS format, the LOPAC library was also screened an additional three times. All 4 compounds of interest were confirmed in the re-screening assays (Table 4).

Altogether the data presented indicate reproducibility and provide a first proof of principle that the GH3.TRE-luc assay is robust and can be utilized to screen large compound libraries in the 1536- well plate format for potential TR agonist as well as antagonist activity.

\section{DISCUSSION}

In the present study, we developed a quantitative highthroughput screen (qHTS) for potential TR agonist and antagonist activity that was based upon the recently developed in vitro reporter gene assay using the stably transfected GH3.TRE-Luc cell line [25]. The assay was miniaturized and validated in a 1536-well plate format. Subsequently the 1280 compounds of the LOPAC library and the 1408 compounds of the NTP collection were tested for their TR agonist or antagonist activity. Of the 2688 compounds tested in the qHTS $8(0.3 \%)$ or $1(0.04 \%)$ were found to be TR agonists depending on whether the positive hit cut off was defined at $\geq 10 \%$ or $\geq 20 \%$ efficacy. None of the inactive compounds was structurally related to $T_{3}$, nor had been reported elsewhere to be a thyroid hormone disruptor, so false negatives do not appear to be present in the screen. Furthermore, none of the low potency TR agonists had structural characteristics that resemble the thyroid hormones (Fig. 1), providing further support that they may not represent effective,direct TR agonists, and therefore may not activate the luciferase gene through direct binding to the TR ligandbinding pocket. Defining TR agonists in the qHTS with a hit cut off of $\geq 20 \%$ efficacy at $100 \mu \mathrm{M}$ may avoid identification of positives that are only very weak agonists and/or not likely to be acting through the ligand-binding pocket. Overall, the GH3.TRE-Luc cells performed very well in an automated 1536-well plate format. The CV slightly varied between $7-11 \%$, but it was well within the performance standards for comparable assays in 1536-well plate format [27].

We used these two chemical collections to validate the highthroughput screen (HTS) because of their diverse chemical spaces, containing compounds proven to be phar- macologically active, and with almost all compounds previously tested in one or more standard toxicological assays. They do not, however, specifically contain compounds known for their in vivo or in vitro thyroid hormone disrupting potency. Not included in the assays were the known $\mathrm{T}_{3}$ and $\mathrm{T}_{4}$-like compounds, Tetrac $(3,5,3$ ',, 5 '-tetraiodothyroacetic acid) and Triac (3,5,3'-triiodothyroacetic acid), or any OH-PCBs (hydroxylated polychlorinated biphenyls), or PBDEs (polybrominated diphenylethers), which had been shown previously to be active in the GH3.TRE-Luc assay [25]. The LOPAC library contains pharmacologically active compounds, including many cytostatic compounds that could cause growth inhibition thereby reducing luciferase activity. For compounds that do not directly antagonize TR activity, cell viability and TRE-Luc inhibition $\mathrm{IC}_{50}$ 's will be similar. Therefore, it is important to quantify cell viability and to calculate the ratio between cell viability and the TRE-Luc inhibition $\mathrm{IC}_{50} \mathrm{~S}$. When this ratio is less than 3 , we assumed the compound to be merely cytotoxic instead of potentially antagonistic of TR activity; this approach has been used before for other reporter gene screens [32]. One of the most potent TRE-Luc antagonists identified in the present screen was the anti-cancer drug 5'-fluorouracil, inducing a full concentration-response curve without apparent cytotoxicity over the range of concentrations used within the $24 \mathrm{~h}$ treatment (Fig. 5). For known cytotoxic compounds like this, it would be worthwhile to evaluate cytotoxicity by alternative methods to provide higher confidence in interpretation of these findings. It is of interest to note that one of the side effects of 5-fluorouracil is cardiotoxicity, the mechanism of which is still poorly understood [33] but has not been linked to TR action to date. In addition, compounds like 5'-fluorouracil induce p53, which in turn is known to interact with and inhibit TR function $[34,35]$. Other potential modes of action of antagonistic compounds are possible that do not require direct TR binding, including inhibition of hormone uptake, induction of hormone export, induction of Type III deiodinase, or inhibition of TR coactivator expression or enzymatic activity. As the cells are used in larger chemicals screens, antagonism via a spectrum of TH- and TRassociated activities versus inhibition of luciferase activity or cell viability will be important to discern in secondary screens.

The most active agonists with $\mathrm{EC}_{50}$ values lower than 10 $\mu \mathrm{M}$ were retinoids detected in both libraries (retinoic acid, trans-retinal, 13-cis-retinoic acid and 13-cis-retinal), and the positive allosteric modulators of the GABA receptors GCP7930 and GCP-13501 (Fig. 3). GABA itself was present in the LOPAC library but did not show any response in this assay, meaning that the GCP compounds may not be activating the reporter gene via the GABA receptor. Retinoic acid is a known direct agonist of both the RAR and the TR heterodimer partner RXR, and the other retinoids may be converted to RAR and/or RXR agonists by intracellular metabolism and isomerization [36]. However, RXRs are generally thought to form "nonpermissive" heterodimers with TRs, RARs,and Vitamin D receptors meaning that RXR ligands are not thought to be able to bind and activate in those complexes. Other nuclear receptors like peroxisome proliferator activated receptors (PPARs) or liver X receptors (LXRs) form "permissive" heterodimers with RXRs that can be acti- 

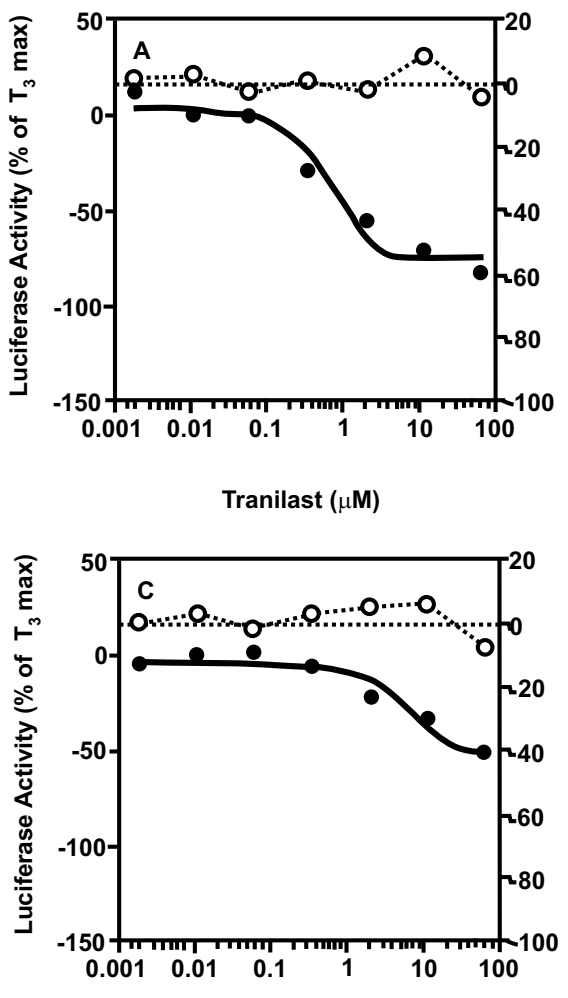

NS-16195 $(\mu \mathrm{M})$

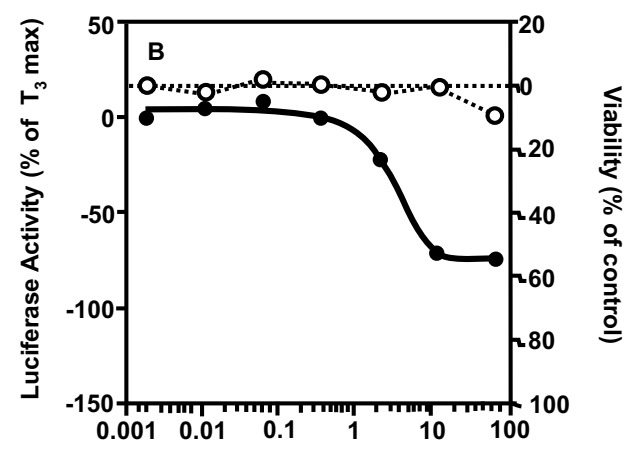

SB $205384(\mu M)$

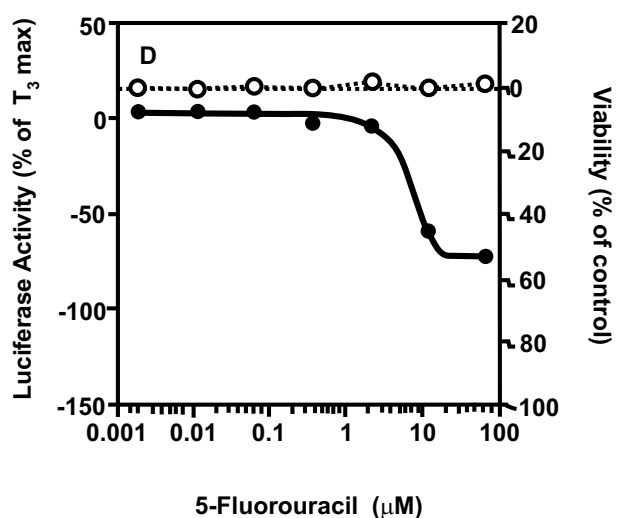

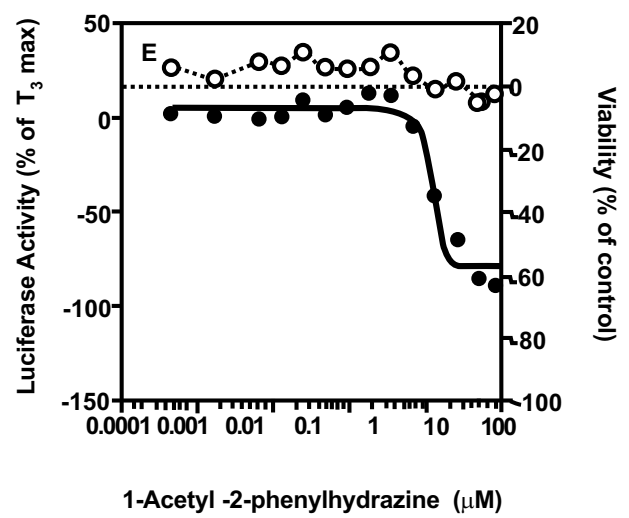

Fig. (5). Examples of antagonists identified in the LOPAC and NTP libraries screening. Open circles, cell viability as a $\%$ of $1 \mathrm{nM} \mathrm{T}_{3}$ alone values; closed circles, luciferase activity as a percentage (\%) of $1 \mathrm{nM} \mathrm{T}_{3}$ alone values, on the right and left y-axes respectively. Ligand concentrations in $\mu \mathrm{M}$ are indicated on the $\mathrm{x}$-axis.

vated by agonists that bind to either partner. In addition, RARs can heterodimerize with TRs and activate the DR4 elements as used in this assay, to some degree in transient transfection assays, in addition to their more preferred DR2 or DR5 arrangements that promote silent, nonpermissive complexes with RXRs [37]. Furthermore, RXR/LXR heterodimers preferentially transactivate DR4 elements, and $\mathrm{GH}_{3}$ cells express functional RXRs [38, 39], RARs [38], and LXRs [40]. However, RARs and LXRs do not activate the reporter gene in these cells as judged by the lack of activity of specific synthetic ligands for these receptors. Thus, it appears likely that the retinoid activity is mediated by RXRs in these cells. Interestingly, the status of RXR as a permissive versus non-permissive partner is defined by the specific cell system used for evaluation. A series of previous studies demonstrated permissive actions of RXRs specifically in pituitary derived cells but not the other cell types [41, 42]. In these rat pituitary derived $\mathrm{GH}_{3}$ cells, RXR in the RXR:TR heterodimer may be permissively modulated by RXR ligands, and thus representing an important functional component of TR signaling in a cell type dependent manner. This would also explain the agonist-like behavior of retinoids in the GH3.TRE-Luc assay without any structural resemblance to $\mathrm{T}_{3}$ or $\mathrm{T}_{4}$. Comparison between the reporter gene activation in the GH3.TRE-Luc versusother cells where RXRs are not permissive in TR heterodimers could be used to filter out RXR-active compounds.

The reporter gene induction potency of other compounds that do not structurally resemble $T_{3}$, is less than that of true 
TR-agonists such as the $\mathrm{T}_{3}$-like OH-BDEs [25]. Therefore the cut-off of a maximum efficacy of $\geq 20 \%$ is also of use to filter out these compounds that are less likely to function as true TR agonists. These less effective activators could still be of interest as they may interact with pathways indirectly modulating TR activation, such as interactions with coregulators or epigenetic modifications like effects on DNA methylation, chromatin structure or miRNA expression patterns, for example.

Important secondary assays in cell lines and in animals should follow to determine whether the GH3.TRE-LUC qHTS assay has good predictive power for effects on thyroid hormone signaling in vivo. For example, we are currently testing agonists and antagonists from this and subsequent larger screens against endogenous thyroid hormone responsive genes in the GH3.TRE-LUC cells. A number of TH regulated genes are expressed in $\mathrm{GH} 3$ cells, including the growth hormone gene that contains the first identified TRE [43]. Compounds affecting endogenous genes are then prioritized for molecular mode of action studies (ligand binding, TRE binding, co activator or corepressor recruitment and other endpoints). Such prioritized compounds will then be tested further in vivo.We plan to first use the induced and spontaneous Xenopus laevis metamorphosis assays that we have used for a number of years to screen synthetic TR agonists and antagonists [44, 45], given the strong conservation of the TRs and other signaling components among vertebrates [46]. Certainly, studies in euthyroid and hypothyroid rodents, during critical windows of development and in the adult may follow for those compounds affecting endogenous genes in cell lines and tadpole development in vivo.

\section{CONCLUSION}

Taken together, the results obtained in the present study demonstrate the potential of the qHTS assay developed here for the identification of novel compounds acting via a TRmediated mode of action. The miniaturized GH3.TRE-Luc assay offers a promising addition to the in vitro test battery for endocrine disruption, and that, given the low percentage of compounds testing positive, its high-throughput nature is an important advantage for future toxicological screening.

\section{CONFLICT OF INTEREST}

The authors confirm that this article content has no conflicts of interest.

\section{ACKNOWLEDGEMENTS}

This research was financially supported by a ZonMW NWO grant (11.400.0075) part of the Alternatives to Animal Experiments Program, and US EPA STAR grant 83516401to JFD and AJM. The Intramural Research Programs of Division of the National Toxicology Program, National Institute of Environmental Health Sciences, National Institutes of Health, as well as the U.S. Environmental Protection Agency also supported this work. The results and interpretations presented here are solely the authors and do not represent an official position of the U.S. EPA.

\section{REFERENCES}

[1] Cheng SY, Leonard JL, Davis PJ. Molecular aspects of thyroid hormone actions. Endocr Rev 2010: 31(2): 139-70.

[2] Bernal J. Thyroid hormone receptors in brain development and function. Nat Clin Pract Endocrinol Metab 2007; 3(3): 249-59.

[3] Horn S, Heuer H. Thyroid hormone action during brain development: more questions than answers. Mol Cell Endocrinol 2010; 315(1-2): 19-26.

[4] Warner A, Mittag J. Thyroid hormone and the central control of homeostasis. J Mol Endocrinol 2012; 49(1): R29-35.

[5] Ribeiro MO. Effects of thyroid hormone analogs on lipid metabolism and thermogenesis. Thyroid 2008; 18(2): 197-203.

[6] Vargas F, Moreno JM, Rodriguez-Gomez I, et al. Vascular and renal function in experimental thyroid disorders. Eur J Endocrinol 2006; 154(2): 197-212.

[7] Yoshimura T. Neuroendocrine mechanism of seasonal reproduction in birds and mammals. Anim Sci J 2010; 81(4): 403-10.

[8] Wagner MS, Wajner SM, Maia AL. The role of thyroid hormone in testicular development and function. J Endocrinol 2008; 199(3): 351-65.

[9] Danzi S, Klein I. Cardiac specific effects of thyroid hormone analogues. Horm Metab Res 2011; 43(11): 737-42.

[10] Kahaly GJ, Dillmann WH. Thyroid hormone action in the heart. Endocr Rev 2005; 26(5): 704-28.

[11] Forrest D, Swaroop A. Minireview: the role of nuclear receptors in photoreceptor differentiation and disease. Mol Endocrinol 2012; 26(6): 905-15.

[12] Gray LE Jr, Ostby J, Marshall R, et al. Reproductive and thyroid effects of low-level polychlorinated biphenyl (Aroclor 1254) exposure. Fundam Appl Toxicol 1993; 20(3): 288-94.

[13] Porterfield SP, Hendry LB. Impact of PCBs on thyroid hormone directed brain development. Toxicol Ind Health 1998; 14(1-2): 103-20.

[14] Lam M, Klasson CE, Wehler M, et al. Structure-dependent, competitive interaction of hydroxy-polychlorobiphenyls, -dibenzop-dioxins and -dibenzofurans with human transthyretin. Chem Biol Interact 1993; 88(1): 7-21.

[15] Hornung MW, Degitz SJ, Korte LM, et al. Inhibition of thyroid hormone release from cultured amphibian thyroid glands by methimazole, 6-propylthiouracil, and perchlorate. Toxicol Sci 2010; 118(1): 42-51.

[16] Biegel LB, Cook JC, O'Connor JC, et al. Subchronic toxicity study in rats with 1-methyl-3-propylimidazole-2-thione (PTI): effects on the thyroid. Fundam Appl Toxicol 1995; 27(2): 185-94.

[17] Darras VM, SL Van Herck. Iodothyronine deiodinase structure and function: from ascidians to humans. J Endocrinol 2012; 215(2): 189-206.

[18] Visser TJ, van Overmeeren E, Fekkes D, et al. Inhibition of iodothyronine 5'-deiodinase by thioureylenes; structure--activity relationship. FEBS Lett 1979; 103(2): 314-8.

[19] Schuur AG, Legger FF, van Meeteren ME, et al. In vitro inhibition of thyroid hormone sulfation by hydroxylated metabolites of halogenated aromatic hydrocarbons. Chem Res Toxicol 1998; 11(9): 1075-81.

[20] Guo GL, Choudhuri S, Klaassen CD. Induction profile of rat organic anion transporting polypeptide 2 (oatp2) by prototypical drug-metabolizing enzyme inducers that activate gene expression through ligand-activated transcription factor pathways. J Pharmacol Exp Ther 2002; 300(1): 206-12.

[21] Murk AJ, Rijntjes E, Blaauboer BJ, et al. Mechanism-based testing strategy using in vitro approaches for identification of thyroid hormone disrupting chemicals. Toxicol In Vitro 2013; 27(4): 132046.

[22] Shukla SJ, Huang R, Austin CP, Xia M. The future of toxicity testing: a focus on in vitro methods using a quantitative highthroughput screening platform. Drug Discov Today 2010; 15(2324): 997-1007.

[23] Huang R, Xia M, Cho MH, et al. Chemical genomics profiling of environmental chemical modulation of human nuclear receptors. Environ Health Perspect 2011; 119(8): 1142-8.

[24] Kavlock RJ, Austin CP, Tice RR. Toxicity testing in the $21^{\text {st }}$ century: implications for human health risk assessment. Risk Anal 2009; 29(4): 485-7; discussion 492-7. 
[25] Freitas J, Cano P, Craig-Veit C, et al. Detection of thyroid hormone receptor disruptors by a novel stable in vitro reporter gene assay. Toxicol In Vitro 2011; 25(1): 257-66.

[26] Xia M, Guo V, Huang R, et al. Inhibition of morphine-induced cAMP overshoot: a cell-based assay model in a high-throughput format. Cell Mol Neurobiol 2011; 31(6): 901-7.

[27] Xia M, Huang R, Kristine LW, et al. Compound cytotoxicity profiling using quantitative high-throughput screening. Environ Health Perspect 2008; 116(3): 284-91.

[28] Sirbasku DA, Pakala R, Sato H, Eby JE. Thyroid hormone dependent pituitary tumor cell growth in serum-free chemically defined culture. A new regulatory role for apotransferrin. Biochemistry 1991; 30(30): 7466-77.

[29] Xia M, Shahane SA, Huang R, et al. Identification of quaternary ammonium compounds as potent inhibitors of hERG potassium channels. Toxicol Appl Pharmacol 2011; 252(3): 250-8.

[30] Zhang JH, Chung TD, Oldenburg KR. A simple statistical parameter for use in evaluation and validation of high throughput screening assays. J Biomol Screen 1999; 4(2): 67-73.

[31] Repa JJ, Turley SD, Lobaccaro JA, et al. Regulation of absorption and ABC1-mediated efflux of cholesterol by RXR heterodimers. Science $2000 ; 289(5484)$ : $1524-9$.

[32] Miller SC, Huang R, Sakamuru S, et al. Identification of known drugs that act as inhibitors of NF-kappaB signaling and their mechanism of action. Biochem Pharmacol 2010; 79(9): 1272-80.

[33] McGlinchey PG, Webb ST, Campbell NP. 5-fluorouracil-induced cardiotoxicity mimicking myocardial infarction: a case report. BMC Cardiovasc Disord 2001; 1: 3.

[34] Bhat MK, Yu Cl, Yap N, et al. Tumor suppressor p53 is a negative regulator in thyroid hormone receptor signaling pathways. $\mathrm{J}$ Biol Chem 1997; 272(46): 28989-93.

[35] Yap N, Yu CL, Cheng SY. Modulation of the transcriptional activity of thyroid hormone receptors by the tumor suppressor p53. Proc Natl Acad Sci USA 1996; 93(9): 4273-7.
[36] Blaner WS. Cellular metabolism and actions of 13-cis-retinoic acid. J Am Acad Dermatol 2001; 45(5): S129-35.

[37] Lee S, Privalsky ML. Heterodimers of retinoic acid receptors and thyroid hormone receptors display unique combinatorial regulatory properties. Mol Endocrinol 2005; 19(4): 863-78.

[38] Davis KD, Lazar MA. Selective antagonism of thyroid hormone action by retinoic acid. J Biol Chem 1992; 267(5): 3185-9.

[39] Davis KD, Berrodin TJ, Stelmach JE, Winkler JD, Lazar MA. Endogenous retinoid $\mathrm{X}$ receptors can function as hormone receptors in pituitary cells. Mol Cell Biol 1994; 14(11): 7105-10.

[40] Matsumoto S, Hashimoto K, Yamada M, Satoh T, Hirato J, Mori M. Liver X receptor-alpha regulates proopiomelanocortin (POMC) gene transcription in the pituitary. Mol Endocrinol 2009; 23(1): 47 60.

[41] Li D, Li T, Wang F, Tian H, Samuels HH. Functional evidence for retinoid $\mathrm{X}$ receptor $(\mathrm{RXR})$ as a nonsilent partner in the thyroid hormone receptor/RXR heterodimer. Mol Cell Biol 2002; 22(16): 5782-92.

[42] Castillo AI, Sánchez-Martínez R, Moreno L, et al. A permissive retinoid $\mathrm{X}$ receptor/thyroid hormone receptor heterodimer allows stimulation of prolactin gene transcription by thyroid hormone and 9-cis-retinoic acid. Mol Cell Biol 2004; 24(2): 502-13.

[43] Koenig RJ, Brent GA, Warne RL, Larsen PR, Moore DD. Thyroid hormone receptor binds to a site in the rat growth hormone promoter required for induction by thyroid hormone. Proc Natl Acad Sci USA 1987; 84(16): 5670-4.

[44] Furlow JD, Yang HY, Hsu M, et al. Induction of larval tissue resorption in Xenopus laevis tadpoles by the thyroid hormone receptor agonist GC-1. J Biol Chem 2004; 279(25): 26555-62.

[45] Lim W, Nguyen NH, Yang HY, Scanlan TS, Furlow JD. A thyroid hormone antagonist that inhibits thyroid hormone action in vivo. $\mathrm{J}$ Biol Chem 2002; 277(38): 35664-70.

[46] Furlow JD, Neff ES. A developmental switch induced by thyroid hormone: Xenopus laevis metamorphosis. Trends Endocrinol Metab 2006; 17(2): 40-7.

(C) Freitas et al.; Licensee Bentham Open.

This is an open access article licensed under the terms of the Creative Commons Attribution Non-Commercial License (http://creativecommons.org/licenses/by-nc/3.0/) which permits unrestricted, non-commercial use, distribution and reproduction in any medium, provided the work is properly cited. 